\title{
Letter \\ CTLA4 polymorphism and primary Sjögren's syndrome
}

\section{Susan Lester ${ }^{1}$, Sarah Downie-Doyle ${ }^{1,2}$ and Maureen Rischmueller ${ }^{2}$}

\author{
${ }^{1}$ Arthritis Research Laboratory, Hanson Institute, South Australia \\ ${ }^{2}$ Rheumatology Department, The Queen Elizabeth Hospital, Woodville Road, Woodville, South Australia
}

Corresponding author: Maureen Rischmueller, Maureen.Rischmueller@nwahs.sa.gov.au

Published: 5 June 2007

This article is online at http://arthritis-research.com/content/9/3/401

Arthritis Research \& Therapy 2007, 9:401 (doi:10.1186/ar2196)

(c) 2007 BioMed Central Ltd

See related research article by Gottenberg et al., http://arthritis-research.com/content/9/2/R24, and related letter by Miceli-Richard et al., http://arthritis-research.com/content/9/3/402

The March 2007 issue of Arthritis Research and Therapy included a research article by Gottenberg and colleagues [1] that reports a failure to confirm our previous study [2] of a genetic association between CTLA4 and primary Sjögren's syndrome (pSS).

Similar to our study, the Gottenberg study analysed both CTLA4 CT60 and +49A/G single nucleotide polymorphisms (SNPs). They observed an association with the +49A/G SNP in one pSS cohort; however, this failed to replicate in a second cohort. We unreservedly agree with the authors' conclusions regarding the importance of replication cohorts. However, we disagree that their results can be interpreted meaningfully against our study.

The CTLA4 CT60 and +49A/G SNPs are haplotype tags for three common, extended CTLA4 haplotypes [3,4], and the main finding of our study was an association between the +49A:CT60G haplotype and autoantibody positive pSS. As we noted in our paper, the individual SNPs occur on multiple haplotypes, and an individual SNP analysis, such as that reported by Gottenberg and colleagues, may result in negative studies or inconsistent findings between studies, particularly if the haplotype frequencies vary between study populations.

In addition to our finding of an association with pSS, the CTLA4 +49A:CT60G haplotype is also associated with systemic lupus erythematosus [5], which shares a number of clinical, serological and genetic features with pSS. A more recent study has identified several haplotype blocks across the extended CD28-CTLA4-ICOS region, with systemic lupus erythematosus associations observed in the distal $3^{\prime}$ flanking region of CTLA4 on a haplotype that includes variants in the promoter of ICOS [6]. Therefore, the balance of evidence supports a genetic association between this region and systemic autoimmune disease, although the precise nature, definition and boundaries of the haplotypes involved remain to be fully defined.

\section{Competing interests}

The authors declare that they have no competing interests.

\section{References}

1. Gottenberg JE, Loiseau P, Azarian M, Chen C, Cagnard N, Hachulla E, Puechal X, Sibilia J, Charron D, Mariette X, MiceliRichard C: CTLA-4 +49A/G and CT60 gene polymorphisms in primary Sjögren syndrome. Arthritis Res Ther 2007, 9:R24.

2. Downie-Doyle S, Bayat N, Rischmueller M, Lester S: Influence of CTLA4 haplotypes on susceptibility and some extraglandular manifestations in primary Sjogren's syndrome. Arthritis Rheum 2006, 54:2434-2440.

3. Amundsen SS, Naluai AT, Ascher H, Ek J, Gudjonsdottir AH, Wahlstrom J, Lie BA, Sollid LM: Genetic analysis of the CD28/ CTLA4/ICOS (CELIAC3) region in coeliac disease. Tissue Antigens 2004, 64:593-599.

4. Munthe-Kaas MC, Carlsen KH, Helms PJ, Gerritsen J, Whyte M, Feijen M, Skinningsrud B, Main M, Kwong GN, Lie BA, et al:: CTLA-4 polymorphisms in allergy and asthma and the TH1/ TH2 paradigm. J Allergy Clin Immunol 2004, 114:280-287.

5. Torres B, Aguilar F, Franco E, Sanchez E, Sanchez-Roman J, Jimenez Alonso J, Nunez-Roldan A, Martin J, Gonzalez-Escribano MF: Association of the CT60 marker of the CTLA4 gene with systemic lupus erythematosus. Arthritis Rheum 2004, 50: 2211-2215.

6. Graham DS, Wong AK, McHugh NJ, Whittaker JC, Vyse TJ: Evidence for unique association signals in SLE at the CD28CTLA4-ICOS locus in a family-based study. Hum Mol Genet 2006, 15:3195-3205. 